\title{
IAMJ
}

INTERNATIONAL

AYURVEDIC

MEDICAL JOURNAL

\section{MANAGEMENT OF GARBHODAKAVRIDDHI W.S.R. TO POLYHYDRAMNIOS THROUGH AYURVEDA - A CASE REPORT}

\section{$\underline{\text { Divya Deepak Patil }}^{1}, \underline{\text { Sonu }}^{2}, \underline{\text { Vipin Tanwar }}^{3}, \underline{\text { Mukesh Chaudhari }}^{4}$}

${ }^{1}$ P.G. Scholar, Department of Prasutitantra and Streeroga, National Institute of Ayurveda, Jaipur, Rajasthan, India ${ }^{1}$ Lecturer, Department of Prasutitantra and Streeroga, National Institute of Ayurveda, Jaipur, Rajasthan, India ${ }^{1}$ Lecturer, Department of Panchakarma, National Institute of Ayurveda, Jaipur, Rajasthan, India ${ }^{1}$ Ph.D Scholar, Department of Rasashastra and Bhaishajyakalpana, National Institute of Ayurveda, Jaipur, Rajasthan, India

Corresponding Author: divyap910@gmail.com

https://doi.org/10.46607/iamj4009072021

(Published Online: July 2021)

Open Access

(C) International Ayurvedic Medical Journal, India 2021

Article Received: 12/06//2021 - Peer Reviewed: 15/06/2021 - Accepted for Publication: 18/06/2021

\section{Check for updates}

\begin{abstract}
Introduction: Polyhydramnios is a relatively common clinical presentation in pregnancy with a varying incidence of 1-2\% of cases. There is yet no data suggestive of improvement in perinatal outcome with antenatal fetal surveillance. Since it is associated with significant perinatal morbidity and mortality, fixing up a standard treatment protocol for its management is needed. Case Description: A 28-year-old female patient consulted Prasutitantra and Streeroga OPD, NIA Hospital, Jaipur complaining of difficulty in breathing, palpitations, hyperacidity for 15 days with 8 months of amenorrhea. Diagnosis: Based on abdominal examination and radiological findings, the case was diagnosed with polyhydramnios. On the correlation of symptoms as stated by Acharya Sushruta, Ayurvedic diagnosis of Garbhavriddhi was made. Intervention: As in the management of garbhavriddhi, practices involving appropriate samshodhana (purifying) and sanshamana (suppressive) yet kshaya-avirodhi karma (not causing loss of dosha or dhatu below optimal range) are prescribed. Hence, an intervention of Ksheerabasti with Punarnavashtaka Kwatha was done along with the oral medication in the present study. Outcome: USG done after 7 days of treatment course showed significant correction in AFI as well relief from clinical symptoms. Conclusion: This
\end{abstract}


case illustrates that Polyhydramnios can be managed effectively and safely with Punarnavashtaka kwatha ksheera basti. Mutrajanana, Srotoshodhana, Kledapachana, and Shothaghna are the main actions essential in its management.

Keywords: Garbhavriddhi, Polyhydramnios, Punarnavashtaka kwatha, Ksheera basti

\section{INTRODUCTION}

Polyhydramnios is one of the common complications in pregnancy which is associated with an increased risk of perinatal morbidity and mortality. It is an amniotic fluid disorder wherein there is excessive accumulation of liquor amnii causing discomfort to the patient. ${ }^{1}$ Factors thought to be involved in the regulation of amniotic fluid involve fetal micturition, deglutition, uterine placental blood flow, fetal respiratory movements. Impairment in the equilibrium of formation and absorption of amniotic fluid due to any of the factors causes excessive amniotic fluid retention called Polyhydramnios. Polyhydramnios sufficient to produce clinical symptoms is reported to occur in one in 1000 pregnancies. Its major causes include GDM, structural and chromosomal fetal anomalies, multiple pregnancies, placental anomalies, and Idiopathic causes ${ }^{2}$. It may lead to preterm birth, maternal compromise, fetal compromise, and increased operative delivery. ${ }^{3}$ In modern science, therapies generally adopted for the management of Polyhydramnios are Indomethacin therapy and Serial amniocentesis ${ }^{4}$ Serial amniocentesis is an invasive procedure whereas Indomethacin therapy has potential hazards on fetal ductus arteriosus. Therefore, alternative management for polyhydramnios is desired for womankind. In Ayurveda, though there is no direct reference to polyhydramnios, Acharya Sushruta stated Garbhavriddhi lakshana as an excessive increase in the size of abdomen and perspiration $^{5}$ which can be correlated as follows:

1. Increased size of the fetus - Macrosomia

2. Excessive amniotic fluid - Garbhodakavriddhi

3. Multiple Pregnancy - Yugma Garbha

In the present case, Garbhavriddhi can be interpreted as Garbhodakavriddhi i.e., polyhydramnios wherein the uterine size is found greater than corresponding gestational age on examination. Considering the specific management of Garbhavriddhi, Samshodhana with Punarnavastaka kwatha Ksheera Basti is planned in this case along with oral medication which found to be effective in treating this condition.

\section{CASE REPORT}

A 28-year female patient with obstetric history G2P2A0L1D0, G1 being FTCS 2.5-year FCH visited Prasutitantra and Streeroga O.P.D., NIA, Jaipur on $10 / 12 / 2020$ complaining of difficulty in breathing, palpitations, burning sensation in the chest for 15 days along with 8 months of amenorrhea. Her LMP was $17 / 04 / 2020$ with a gestation age of 33 weeks 6 days and EDD was on 24/01/2021. This was her first visit as she has visited the local private hospital for routine ANC check-ups before.

\section{CLINICAL FINDINGS}

The patient's general condition was healthy with mild pitting edema over bilateral feet. Her vitals were stable, BP being 130/70 mmHg, PR 76/minute, RR $26 /$ minute with temperature $97.6^{0} \mathrm{~F}$. Her height was $157 \mathrm{~cm}$ and her weight was $78 \mathrm{~kg}$. Per abdominal examination revealed tensed-shiny abdomen with fundal height corresponding to 34-36 weeks of gestation which is more than the period of amenorrhea. FHR was $148 / \mathrm{bpm}$ with Doppler. There were no uterine contractions as well as no tenderness over the abdomen. The patient was admitted to I.P.D., Prasutitantra and Streeroga department, NIA, Jaipur for further management.

DIAGNOSTIC ASSESSMENT: Routine investigations were advised to the patient after admission which was within normal limit. The patient already had a USG report with details as follow: 
Table 1: USG investigation on $1^{\text {st }}$ visit before treatment.

Date: $02 / 09 / 2020$

Single live intrauterine pregnancy is seen.

Fetal cardiac pulsation

Fetal movements

Amniotic fluid

Umbilical cord

Placenta

Cervical length

Internal os

Impression: Live intrauterine pregnancy of approx. 20 weeks 2 days with polyhydramnios and normal fetoplacental blood flow pattern.

Based on the patient's complaints of difficulty in breathing, Per-abdominal findings and USG findings i.e. increased amniotic fluid with $7 \mathrm{~cm}$ DVP, a diagnosis of Garbhodakavriddhi ie. Mild Polyhydramnios is made.

\section{THERAPEUTIC INTERVENTION}

While prescribing specific management of Garbhavriddhi Acharya Sushruta suggested the use of Sanshodhana (purifying) and Kshaya avirodhi kriya (suppressing the increased dosha not causing loss of that dosha). Basti is the Sanshodhana suggested by Acharya Sushruta in the $8^{\text {th }}$ month of pregnancy. Also, being the route of drug administration allowing extensive drug absorption it is planned in this case. Considering imbalance in the equilibrium of formation and absorption of liquor amnii, the drug with kledapachaka (Absorbing excessive moisture) mootrala (diuretic) and shothaghna karma (Anti-inflammatory) must be thought of for the intervention. Punarnavashtaka Kwatha is a polyherbal formulation mentioned in Bhaishajya ratnavali ${ }^{6}$. It has an established diuretic, anti-inflammatory properties and is indicated in diseases like Sarvanga Shotha (Generalized Edema), Udara roga (Abdominal Disorders). It is comprised of the ingredients mostly dominated by $t i k$ shna (penetrating), Ushna (hot in potency), Ruksha (dry) properties. As Tikshna and Ushna drugs are contraindicated in garbhini (pregnant lady), Ksheerapaka is the formulation of choice to combat tikshna ushna and ruksha properties of punarnavasthaka kwatha. An associated symptom like a burning sensation in the chest was also present in this case. An oral combination of avipattikara churna, Pittantaka yoga, Pravala pishti and Kapardika bhasma has been effective in treating hyperacidity symptoms. Therefore, in the present case, Ayurveda treatment modality including Ksheera basti prayoga with Punarnavashtaka Kwatha along with an oral combination of avipattikara churna adi has been adopted.

\section{COURSE OF TREATMENT}

The patient was given Punarnavashtaka kwatha ksheera basti once a day for 7 days without any prior snehana and swedana karma. Basti was prepared as per standard procedure of ksheerapaka mentioned by Yadavji Trikamji Acharya ${ }^{7}$, Luke warmed and was administered rectally in nyubjavastha ie. Hunchbacked with knee flexed position.

Table 2: Punarnavashtaka Kwatha Ksheera Basti

\begin{tabular}{|c|c|c|c|c|c|}
\hline Drug & Part & Dose & Position & $\begin{array}{l}\text { Route of Ad- } \\
\text { ministration }\end{array}$ & Duration \\
\hline $\begin{array}{l}\text { Punarnavashtaka } \\
\text { Kwatha Choorna } \\
(30 \mathrm{gm}) \\
+ \text { Gavya ksheera } \\
(500 \mathrm{ml}) \\
+ \text { Water }(500 \mathrm{ml})\end{array}$ & $\begin{array}{l}1 \text { Part } \\
15 \\
\text { Parts } \\
15 \\
\text { Parts }\end{array}$ & $\begin{array}{l}500 \mathrm{ml} \text { of Ksheera paka of } \\
\text { Punarnavashtaka Choorna }\end{array}$ & $\begin{array}{l}\text { Bent or } \\
\text { Hunchbacked } \\
\text { Position } \\
\text { (Nyubja- } \\
\text { vastha) }\end{array}$ & $\begin{array}{l}\text { Per rectal } \\
(\text { Guda } \text { marga })\end{array}$ & $\begin{array}{l}\text { For } 7 \text { consecutive days in } \\
\text { the morning after break- } \\
\text { fast }\end{array}$ \\
\hline
\end{tabular}


A combination of drugs containing Avipattikara churna, Pittantaka churna, Kapardika bhasma and Pravala pishti, each manufactured at Pharmacy, NIA, Jaipur was given orally for 7 days to relieve the hyperacidity symptoms.

Table 3: Internal Medication ${ }^{8}$

\begin{tabular}{|l|l|l|l|l|l|l|}
\hline $\begin{array}{l}\text { Sr. } \\
\text { No. }\end{array}$ & Drug & Dose & $\begin{array}{l}\text { Time of administra- } \\
\text { tion }\end{array}$ & $\begin{array}{l}\text { Vehicle } \\
\text { (Anupaana) }\end{array}$ & $\begin{array}{l}\text { Dura- } \\
\text { tion }\end{array}$ & \\
\hline 1. & $\begin{array}{l}\text { Avipattikara } \\
\text { Choorna }\end{array}$ & $3 \mathrm{gm}$ & $\begin{array}{l}\text { Before Meal } \\
\text { (Apaanakala) }\end{array}$ & Water & $\begin{array}{l}\text { For } 7 \\
\text { days }\end{array}$ & $\begin{array}{l}\text { Reduction in acid secretion } \\
\text { Anti-ulcer activity }\end{array}$ \\
\hline 2. & $\begin{array}{l}\text { Pittantaka } \\
\text { Choorna }\end{array}$ & $1 \mathrm{gm}$ & & & $\begin{array}{l}\text { Gastric antiulcer } \\
\text { Anti-secretary activity }\end{array}$ \\
\hline 3. & $\begin{array}{l}\text { Kapardika } \\
\text { Bhasma }\end{array}$ & $500 \mathrm{mg}$ & & & $\begin{array}{l}\text { Kshareeya (Alkaline) } \\
\text { Deepana, Pachana, Amlapiita, } \\
\text { Agnimandya }\end{array}$ \\
\hline 4. & Pravala Pishti & $500 \mathrm{mg}$ & & \\
\hline
\end{tabular}

\section{TREATMENT OUTCOME}

The patient was observed for 7 days during Bastikarma. There was no occurrence of any unwanted signs or symptoms during treatment. There was not any burning sensation in the abdomen by $4^{\text {th }}$ day of treatment. Pedal edema was relieved by the $6^{\text {th }}$ day of the treatment course. Difficulty in breathing was completely relieved by the end of the course. USG carried out after completion of treatment showed Amniotic fluid inadequate amount with AFI- $17.4 \mathrm{~cm}$.

Table 4: USG Findings After Course of Treatment

Date: $23 / 12 / 2020$

Single live intrauterine pregnancy is seen with a cephalic presentation in the LOA position.

Fetal cardiac pulsation - Present, Regular (FHR: 130/bpm)

Fetal movements - Present

Amniotic fluid

- Adequate (AFI- $17.4 \mathrm{~cm}$ )

Placenta

- Anterior, mid uterine, mostly right-sided,

Cervix

Normal Placental perfusion was seen on color Doppler.

- Normal

Impression: single live intrauterine pregnancy with G.A. 35 weeks 2 days is seen with a cephalic presentation in LOA position. 


\section{MODE OF ACTION}

Table 5: Ingredients of Punarnavashtaka Kwatha Churna formulated at Pharmacy, NIA, Jaipur along with Properties $^{9}$

\begin{tabular}{|c|c|c|c|c|c|c|c|}
\hline Sr. N. & Drug & Latin Name & Family & $\begin{array}{l}\text { Part } \\
\text { Used }\end{array}$ & $\begin{array}{l}\text { Quan- } \\
\text { tity }\end{array}$ & $\begin{array}{l}\text { Rasa/Veerya/ } \\
\text { Vipaka }\end{array}$ & Properties \\
\hline 1 & $\begin{array}{l}\text { Punar- } \\
\text { nava }\end{array}$ & $\begin{array}{l}\text { Boerhavia dif- } \\
\text { fusa Linn. }\end{array}$ & $\begin{array}{l}\text { Nyctagi- } \\
\text { naceae }\end{array}$ & Root & 1 Part & $\begin{array}{l}\text { Katu, } \\
\text { Katu, } \\
\text { Sheeta }\end{array}$ & $\begin{array}{l}\text { Tridoshahara (Corrects vitiated } \\
\text { doshas), Shothaghna, } \\
\text { Anulomana } \\
\text { Diuretic by increasing renal } \\
\text { blood flow }\end{array}$ \\
\hline 2 & Abhaya & $\begin{array}{l}\text { Terminalia } \\
\text { chebula Retz. }\end{array}$ & $\begin{array}{l}\text { Combre- } \\
\text { taceae }\end{array}$ & Fruit & 1 Part & $\begin{array}{l}\text { Lavanavarjita } \\
\text { Pancharasa, } \\
\text { Madhura, } \\
\text { Ushna }\end{array}$ & $\begin{array}{l}\text { Laghu, Rukshsa, } \\
\text { Tridoshahara, Prajasthapana, } \\
\text { Anulomana, Rasayana, Lekhana }\end{array}$ \\
\hline 3 & Nimba & $\begin{array}{l}\text { Azadirachta } \\
\text { indica Linn. }\end{array}$ & Meliaceae & Bark & 1 Part & $\begin{array}{l}\text { Tikta, } \\
\text { Katu, } \\
\text { Sheeta }\end{array}$ & $\begin{array}{l}\text { Laghu, } \\
\text { KaphapittashamakaYakrut Ut- } \\
\text { tejaka, } \\
\text { Diuretic, Astringent, Immuno- } \\
\text { protective }\end{array}$ \\
\hline 4 & Darvi & $\begin{array}{l}\text { Berberis aris- } \\
\text { tata DC. }\end{array}$ & $\begin{array}{l}\text { Berberi- } \\
\text { daceae }\end{array}$ & $\begin{array}{l}\text { Rhi- } \\
\text { zome }\end{array}$ & 1 Part & $\begin{array}{l}\text { Tikta, } \\
\text { Katu, } \\
\text { Ushna }\end{array}$ & $\begin{array}{l}\text { Laghu, Ruksha } \\
\text { Kapha-pittahara Inhibits water } \\
\text { retention, Anti-inflammatory, } \\
\text { Relieves Edema. }\end{array}$ \\
\hline 5 & Tikta & $\begin{array}{l}\text { Picrorhiza kur- } \\
\text { roa Royle ex } \\
\text { Benth. }\end{array}$ & $\begin{array}{l}\text { Scrophu- } \\
\text { lariaceae }\end{array}$ & Root & 1 Part & $\begin{array}{l}\text { Tikta } \\
\text { Katu } \\
\text { Sheeta }\end{array}$ & $\begin{array}{l}\text { Laghu, Ruksha } \\
\text { Kaphapittashamaka } \\
\text { Mild Purgative, Diuretic } \\
\text { Prevents UTIs, Reduces Edema } \\
\text { Appetizer in small doses }\end{array}$ \\
\hline 6 & Patola & $\begin{array}{l}\text { Trichosanthes } \\
\text { diocia Roxb. }\end{array}$ & $\begin{array}{l}\text { Cucurbi- } \\
\text { taceae }\end{array}$ & Leaves & 1 Part & $\begin{array}{l}\text { Tikta } \\
\text { Katu } \\
\text { Ushna }\end{array}$ & $\begin{array}{l}\text { Laghu, Ruksha } \\
\text { Tridoshashamaka } \\
\text {, Mild Purgative, Anti-inflam- } \\
\text { matory }\end{array}$ \\
\hline 7 & Guduchi & $\begin{array}{l}\text { Tinospora cor- } \\
\text { difolia (Willd.) } \\
\text { Meirs }\end{array}$ & $\begin{array}{l}\text { Menisper- } \\
\text { maceae }\end{array}$ & Stem & 1 Part & $\begin{array}{l}\text { Tikta } \\
\text { Madhura } \\
\text { Ushna }\end{array}$ & $\begin{array}{l}\text { Laghu, Snigdha } \\
\text { Tridoshashamaka, Vishaghna } \\
\text { Anti-secretary } \\
\text { Digestive, Anti-inflammatory, } \\
\text { Diuretic, Immunostimulant }\end{array}$ \\
\hline 8 & Nagara & $\begin{array}{l}\text { Zingiber offici- } \\
\text { nale Roscoe. }\end{array}$ & $\begin{array}{l}\text { Zinzibera- } \\
\text { ceae }\end{array}$ & $\begin{array}{l}\text { Rhi- } \\
\text { zome }\end{array}$ & 1 Part & $\begin{array}{l}\text { Katu, } \\
\text { Ushna, } \\
\text { Madhura }\end{array}$ & $\begin{array}{l}\text { Laghu, Snigdha Vatakaphahara, } \\
\text { Antiflatulent } \\
\text { Deepana, bhedana }\end{array}$ \\
\hline
\end{tabular}

\section{DISCUSSION}

Punarnavashtaka Kwatha is a polyherbal formulation. A polyherbal formulation is known to have greater therapeutic efficacy due to the synergism of its components. Most of its ingredients possess laghu-ruksha guna, tikta-katu rasa, Katu-vipaka and ushna veerya which acts probably as follows ${ }^{10}$.

It consists of Punarnava which has been depicted as the best mootrala and shothahara drug effectively excreting excessive fluid through urine and reducing 
edema. The rest of its constituents have srotovishodhaka and kleda-pachaka property which reduces fluid retention in the body. Guduchi shows anti secretary property preventing the excessive formation of liquor amnii. Rasayana property of punarnava, shunthi and guduchi enhanced immunity of mother as well as fetus against diseases. Ksheerpaka formulation has a nutritive effect on the fetus as well as on the mother. Thus, Punarnavashtaka Kwatha Ksheerapaka maintains optimal fetal growth so that fetal weight was not reduced with a reduction in the amount of liquor amnii. Administration of drugs in basti form helps in samshodhana karma as well as enhances bioavailability of drug leading to its maximum absorption. Basti also causes anulomana of vayu thereby relieving breathing difficulty. Considering the burning sensation in the chest, a combination of Avipattikara Churna, Pittantaka Churna, Praval Pishti and Kapardika Bhasma is given to the patient for oral administration along with bastikarma modality. Gastroprotective, as well as the mild laxative property of the combination, subsides a burning sensation in the chest. Pittantaka choorna is ayurvedic proprietary medicine prepared in Pharmacy, NIA, Jaipur. It contains Swarna gairika which by its madhura kashaya rasa and sheeta veerya balances vitiated pitta along with sita. Pravala pishti and kapardika bhasma are calcium-containing ayurvedic preparation. Pravala Pishti by its madhura rasa and sheeta guna pacifies amlaguna of pitta relieving amlapitta symptoms. Kapardika bhasma neutralizes pitta (Gastric acid) by its kshareeya property. Also, it potentiates the effects of other drugs in the combination. Calcium ions released from these two enhances protective mechanism of gastric mucosa against acid ${ }^{11}$. Endowed with a diuretic, anti-inflammatory, immune-modulatory, and acid-neutralizing property, the treatment modality works well against polyhydramnios without harming fetal health.

\section{CONCLUSION}

Based on the outcome of the treatment and discussion, it is concluded that ksheerabasti with Punarnavashtaka kwatha merely for 7 days holds a signifi- cant role in maintaining physiological equilibrium between production and excretion of liquor amnii. Also, bastikarma relieves pressure symptoms like difficulty in breathing caused due to polyhydramnios. A combination of Avipattikara churna, Pittantaka churna, Pravala pishti and Kapardika bhasma is amazingly effective in treating hyperacidity symptoms. Hence, the selection of Punarnavashtaka Kwatha Ksheera Basti along with some oral drug administration as per secondary complaints is apt to treat polyhydramnios. As this is a single case report, more such case studies are needed for fixing up the standard treatment protocol in this condition.

\section{REFERENCES}

1. DC Dutta. Textbook of Obstetrics including Perinatology and Contraception, Polyhydramnios $9^{\text {th }}$ Edition, Page 200

2. Hamza A, Herr D, Solomayer EF, Meyberg-Solomayer G. Polyhydramnios: Causes, Diagnosis and Therapy. Geburtshilfe Frauenheilkd. 2013;73(12):12411246. doi:10.1055/s-0033-1360163

3. Cardwell MS. Polyhydramnios: a review. Obstet Gynecol Surv. 1987 Oct;42(10):612-7. DOI: 10.1097/00006254-198710000-00001. PMID: 3118281

4. Sakshi AH, Self-assessment and Review Obstetrics, $10^{\text {th }}$ edition, The Health Sciences Publishers, New Delhi, Placenta, fetal membranes, umbilical cord and Amniotic fluid, p: 23

5. Sushruta Samhitaby Kaviraja Ambikadutta Shastri Chaukhamba Sanskrit Sansthan, Varanasi, Sutra Sthana $15^{\text {th }}$ chapter $16^{\text {th }}$ Shloka.

6. Kavirajshri Ambikadattashastri Ayurvedacharya. Bhaishajya Ratnavali. Varanasi; Chaukhambha Sanskrit Samsthan; 2002. p. 532.

7. Yadavji Trikamji Acharya. Dravya guna Vignana, $2^{\text {nd }}$ Edition. Mumbai; Satyabhamabaipanduranga Nirnayasagaramudrana Yantralaya; 1947. p. 33-34.

8. Singh, A., et al. "Anti-Ulcer Activity Of Calcium Based Ayurvedic Bhasmas And Pishti Prepared From MarineSourced Animals." Electronic Journal of Pharmacology and Therapy 2 (2009): 71.

9. Ayurvedic Pharmacology and Therapeutic Use of Medicinal Plants, Vaidya Vishnu Mahadev Gogte, Chaukhambha Publications, New Delhi. 
10. Vaidya VM Gogte. Ayurvedic Pharmacology and Therapeutic Uses of Medicinal Plants, Dravyagunavijnana. New Delhi; Chaukhambha publications; 2012. p.113

11. Singh A, Dubey SD, Reddy KR, Patne S, Kumar V. Anti-Ulcer Activity Of Calcium Based Ayurvedic Bhasmas And Pishti Prepared From Marine-Sourced Animals. Electronic Journal of Pharmacology and Therapy. 2009 Jan 1; 2:71.

\section{Source of Support: Nil}

\section{Conflict of Interest: None Declared}

How to cite this URL: Divya Deepak Patil et al: Management Of Garbhodakavriddhi W.S.R. To Polyhydramnios Through Ayurveda - A Case Report. International Ayurvedic Medical Journal \{online\} 2021 \{cited July 2021\} Available from: http://www.iamj.in/posts/images/upload/1564_1570.pdf 